\title{
Cost-Effectiveness Analysis of Sewer Mining versus Centralized Wastewater Treatment: Case Study of Arga River Basin (Spain)
}

M González-Viar ${ }^{\mathrm{a}^{*}}$, R Díez-Montero ${ }^{\mathrm{a}}$, M Molinos-Senante ${ }^{\mathrm{b}, \mathrm{c}}, \mathrm{L}^{\mathrm{N}}$ De-Florio ${ }^{\mathrm{a}}$, AL Esteban-García ${ }^{\mathrm{a}}$, R Sala-Garrido ${ }^{\mathrm{b}}, \mathrm{F}$ Hernández-Sancho ${ }^{\mathrm{d}}$ and I Tejero ${ }^{\mathrm{a}}$ ${ }^{a}$ Department of Sciences and Techniques of Water and the Environment, University of Cantabria, Santander, Spain; ${ }^{b}$ Department of Mathematics for Economics, University of Valencia, Valencia, Spain; 'Division of Economics, University of Stirling, Stirling, UK; ${ }^{d}$ Department of Applied Economics II, University of Valencia, Valencia, Spain

*Corresponding author: Marta González-Viar

Department of Sciences and Techniques of Water and the Environment, University of Cantabria, Avda.de los Castros s/n, 39005, Santander, Spain. Tel: +34 942202 286; Fax: +34 942201 703; email: gonzalezvm@unican.es

Rubén Díez-Montero

Department of Sciences and Techniques of Water and the Environment, University of Cantabria, Avda.de los Castros s/n, 39005, Santander, Spain. Tel: +34 942202 286; Fax: +34 942201 703; email: dmonteror@unican.es

María Molinos-Senante

Department of Applied Economics II,University of Valencia,Avda. Tarongers s/n, 46022, Valencia, Spain and Division of Economics, University of Stirling,FK9 4LA, Stirling, United Kingdom. Tel: +34 963828 349; Fax: +34 963828 354; email: maria.molinos@uv.es

Loredana De-Florio

Department of Sciences and Techniques of Water and the Environment, University of Cantabria, Avda.de los Castros s/n, 39005, Santander, Spain. Tel: +34 942202 286; Fax: +34 942201 703; email: loredana.deflorio@istruzione.it 
Lorena Esteban-García

Department of Sciences and Techniques of Water and the Environment, University of Cantabria, Avda.de los Castros s/n, 39005, Santander, Spain. Tel: +34 942202 296;

Fax: +34 942201 703; email: estebana@unican.es

Ramón Sala-Garrido

Department of Mathematics for Economics, University of Valencia, Avda. Tarongers s/n, 46071, Valencia, Spain. Tel: +34 963828 398; Fax: +34 963828 370; email: ramon.sala@uv.es

Francesc Hernández-Sancho

Department of Applied Economics II, University of Valencia, Avda. Tarongers s/n, 46022, Valencia, Spain. Tel: +34 963828 336; Fax: +34 963828 354; email:

francesc.hernandez@uv.es

Iñaki Tejero

Department of Sciences and Techniques of Water and the Environment, University of Cantabria, Avda. de los Castros s/n, 39005, Santander, Spain. Tel: +34 942201 802; Fax: +34 942201 703; email: tejeroi@unican.es

The Version of Record of this manuscript has been published and is available in Urban Water Journal, 3 January 2015. http://www.tandfonline.com/10.1080/1573062X.2014.991742. 


\section{Cost-Effectiveness Analysis of Sewer Mining versus Centralized Wastewater Treatment: Case Study of Arga River Basin (Spain)}

In the context of the EU Water Framework Directive, a Cost-Effectiveness Analysis (CEA) was performed to compare centralized and decentralized wastewater treatment strategies aimed to improve the ecological status of a Spanish river. The implementation of several hybrid membrane bioreactors within the urban framework for sewer mining (SM) was compared with the more common wastewater treatment plant enlargement option. The assessment ranked 6 alternatives based on 12 potential scenarios, aimed at narrowing the uncertainty of the CEA. The cost analysis illustrated that SM is the most expensive option regarding both investment and operation and maintenance costs. However, the effectiveness of the alternatives evaluated depends significantly on the scenarios considered, being SM the most effective in most cases. Finally, the costeffectiveness ratio showed SM as the best cost-effective alternative. CEA provides an ecological-economic indicator useful to prioritize wastewater treatment alternatives to achieve a given objective.

Keywords: cost-effectiveness analysis; hybrid membrane bioreactor; sewer mining; economics; decentralized wastewater treatment

\section{Introduction}

The European Union Water Framework Directive, WFD 2000/60/CE, adopted in year 2000, has supposed a significant reform of water management in Europe. The ultimate aim of the WFD is to achieve the good ecological status of the European water bodies. A key differentiating element is the role that economic tools and principles have been assigned in the WFD (Van Engelen et al.2008, Xenarios 2009,Berbel et al. 2011, Martín-Ortega 2012). To fulfil the environmental objectives of the WFD, each river water basin should have undertaken a program of measures (PoM) by 2009 which shall be reviewed and updated at the latest 15 years after the date of entry into force of the WFD and every 6 years thereafter. Therefore, the PoM issue has set the water agenda in the last 10 years and will continue to do so. 
There are two basic methods to economically assess water management programs namely cost-benefit analysis (CBA) and cost-effectiveness analysis (CEA). Even though CBA has the advantage of measuring the net benefits of each alternative in monetary terms ensuring the economic rationality of investments, within the WFD context, the most widely accepted method is CEA (Berbel et al. 2011, Molinos-Senante et al. 2011) because it allows for the outcome of the PoM to be evaluated in terms of physical units avoiding the complex processes of economic valuation.

Since CEA was proposed by the WATECO group (European Commission 2003) as a method to assess the PoM linked to the WFD, it has been used across Europe following different methodological approaches for several purposes (Balana et al. 2011, Perní and Martínez-Paz 2013). It has been widely applied to assess the costeffectiveness of several strategies to control diffuse pollution and to mitigate eutrophication (Vinten et al. 2012, Mewes 2012, Panagopoulos et al. 2013) or to reduce water abstraction in areas of water stress (Blanco-Gutiérrez et al. 2011). In short, CEA provides an ecological-economic indicator to compare and evaluate strategies to achieve a certain objective.

One of the most significant environmental problems identified for many Mediterranean water bodies is related to summer low flow episodes leading to nitrogen and phosphorus pollution (European Commission 2007). The main source of these problems comes from water extraction together with pollution from farms and sewage works. Therefore, to achieve the good ecological status of water bodies, two kinds of measures can be implemented: those aimed at saving water and those designed to reduce pollution (Álvarez-Farizo and Hanley 2006). Because it has been accounted that wastewater discharges from wastewater treatment plants (WWTP) can represent a high percentage of the total stream flow -up to $90 \%$ during summer time- a significant 
number of measures within the WFD are aimed at improving wastewater treatment including water reclamation (Molinos-Senante et al. 2011).

Sewer mining (SM) consists of extracting wastewater from a sewer system, treating it using physical, chemical and/or biological onsite satellite treatment plants, close to the site for reuse, thus producing reclaimed water suitable for specific end use (McFallan and Logan 2008). It has been considered a sustainable management of water resources option to incorporate into urban development (Chanan and Woods 2006, Suriyachan et al. 2012, Dobbie and Brown 2014), also in developing countries (Massoud et al. 2009). Advantages of decentralized wastewater treatment (DWWT) versus widely used centralized wastewater treatment (CWWT) strategies are being largely discussed (Kamal et al. 2008, Libralato et al. 2012, Poustie et al. 2014). Nevertheless, most of the studies have focused on comparing both strategies from a technical point of view but not from an economic perspective.

There are a number of technologies validated at large-scale as reliable for obtaining reclaimed water (particularly advanced membrane solutions), unfavourable economics being the claimed obstacle for their application. This is mainly because of the reuse facilities such as transport pipelines, storage tanks and recycled water pumps (Butler and MacCormick 1996). Membrane systems have a high level of automation due to their mechanical configuration and need for continuous fouling management. This can readily be extended to the whole plant, to provide a completely automated system suited for decentralized or satellite treatment facilities (Kraemer et al. 2012) and to apply for sewage (Sartor et al. 2008) or grey water treatment (Jaboring 2014)in sites without a sewer system.

Membrane bioreactors (MBR) are very efficient for pathogenicity removal and capable of meeting other parameters for irrigation water quality such as heavy metals 
(Arévalo et al. 2013, Norton-Brandão et al. 2013) or endocrine disruptor compounds and pharmaceuticals (Le Minh et al. 2010). Besides, hybrid membrane bioreactor (HMBR) incorporates fixed bed biofilm (Rodríguez-Hernández et al. 2012) providing some operational advantages over conventional MBR (Rodríguez-Hernández et al. 2014).

This contribution is focused on the reduction of the impact of WWTP discharge into a river, by means of: (i) an improvement in its quality (CWWT alternative); (ii) a reduction of its quantity coupled with the release of dammed water (DWWT alternative by SM). These alternatives can significantly increase the resilience status of the receiving water body, even though additional measures for the achievement of the overall WFD requirements could be needed.

The aim of this paper is to compare such alternatives by means of CEA in a case study and illustrate the usefulness of this analysis to prioritize measures.

Membrane technology is applied to obtain reclaimed water in both cases but for different applications: environmental (river discharge) and urban/agricultural uses (irrigation), respectively. The centralized, Advanced Tertiary Treatment (ATT) consists on membrane ultrafiltration, while decentralized management by applying HMBR is the alternative considered as SM technology. For comparison purposes, a centralized, Conventional Tertiary Treatment (CTT) is also evaluated.

To narrow uncertainty and to assess different situations, two discount rates and twelve scenarios with different river and discharge flows and qualities were analysed.

\section{Materials and Methods}

\section{Case Study}

The hypothetical application case here presented refers to the Arga river basin where the urban area of Pamplona (Navarra, Spain) and its industrial surroundings are located, with a population equivalent of 700,000 inhabitants. The case study is placed in a 
management and control unit area, identified to facilitate the future implementation of WFD, limited by the points where the Arga converges with the Elorz and the Arakil rivers (Figure 1). The Arga ecotype before the Arakil convergence is defined as "limestone wet mountain river", thereafter, where most of the concerns are noted, its ecotype is defined as a "low mineralised continental Mediterranean axis river" (Castiella et al. 2007, Orden ARM/2656, 2008). The Arga River is dammed in the Eugi, a head reservoir that mainly serves to supply fresh water. Finally, Arga empties into the Aragon River, tributary of Ebro River. That river basin, the largest in Spain, is highlighted as an example of the Spanish Mediterranean rivers and streams threats (Cooper et al. 2013, Grantham et al. 2013).

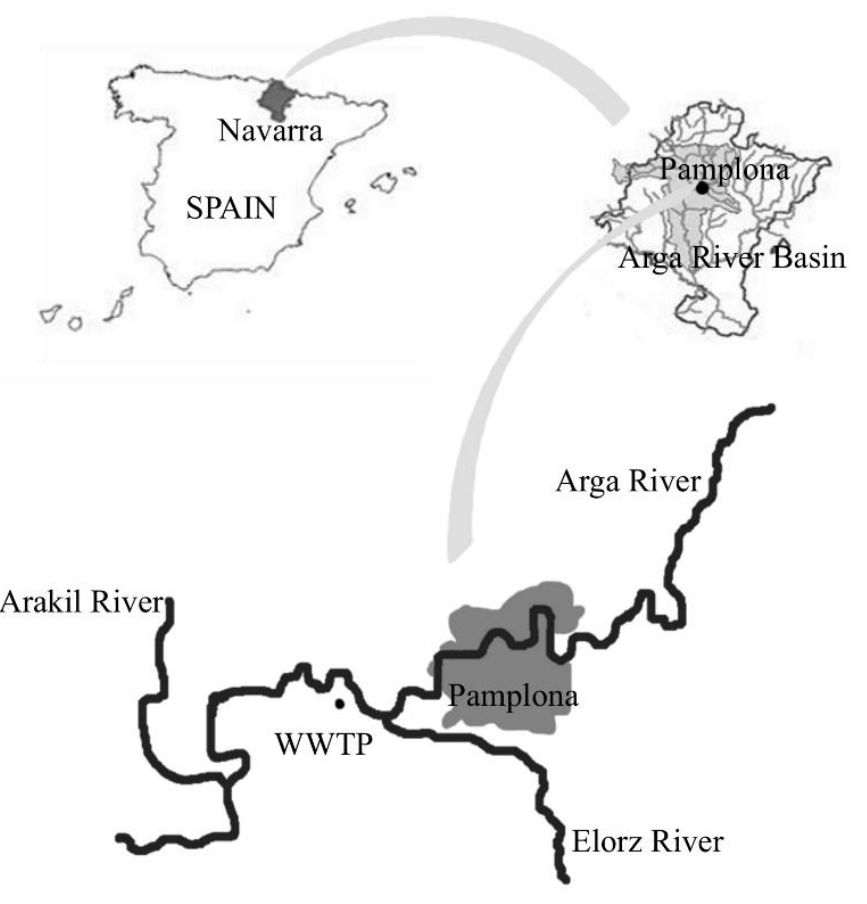

Figure 1. Case study location: Pamplona, WWTP, Arga River, Elorz River and Arakil River on Arga River Basin, Navarra, Spain.

Concerning wastewater management, $99 \%$ of wastewater from the whole area is collected and treated in a single WWTP finally discharging into the river. The WWTP 
effluent meets the requirement of discharge permit. Nevertheless, during the dry season, the reduction of the water availability implies that a large fraction of the river flow comes from the WWTP discharge or irrigation return-flows, containing mineral and organic loads. Similar problems are frequent in Mediterranean streams (González del Tánago et al. 2012). Even though the good quality drinking water supply is guaranteed, the Ebro Hydrographic Confederation (River Basin District Water Authority) stated that 'the Arga water flow, downstream Pamplona, is highly at risk of not meeting the 2015 objective'. A number of studies have been carried out at river basin level with the aim of increasing the Arga water quality. Among the measures proposed, the following are highlighted: increase of the river flow upstream by shutting down certain uses (with due compensation); reduction of the overflow of untreated wastewater by intervention on the sewer system (stormwater tanks); intervention on the diffuse pollution related to agricultural fertilizer or livestock manure runoff; reduction of the impact of WWTP discharge (Castiella et al. 2007).

The river flow rate during dry season estimated by the 7Q10 method, which Smakhtin (2001) defined as 'the lowest average flows that occur for a consecutive 7-day period at the recurrence intervals of 10 years', hardly reaches $0.5 \mathrm{~m}^{3} / \mathrm{s}$ upstream the WWTP. Meanwhile, the WWTP discharges an average flow of $1 \mathrm{~m}^{3} / \mathrm{s}$. The water qualities of these flows are shown in Table 1. 
Table 1. River upstream, WWTP ${ }^{\mathrm{a}}, \mathrm{ATT}^{\mathrm{b}}$ and $\mathrm{CTT}^{\mathrm{c}}$ effluent quality values.

\begin{tabular}{cccccc} 
& $\begin{array}{c}\mathrm{TSS}^{\mathrm{d}} \\
(\mathrm{mg} / \mathrm{L})\end{array}$ & $\begin{array}{c}\mathrm{BOD}^{\mathrm{e}} \\
(\mathrm{mg} / \mathrm{L})\end{array}$ & $\begin{array}{c}\mathrm{PO}_{4}-\mathrm{P}^{\mathrm{f}} \\
(\mathrm{mg} / \mathrm{L})\end{array}$ & $\begin{array}{c}\mathrm{NH}_{4}-\mathrm{N}^{\mathrm{g}} \\
(\mathrm{mg} / \mathrm{L})\end{array}$ & $\begin{array}{c}\mathrm{NO}_{3}-\mathrm{N}^{\mathrm{h}} \\
(\mathrm{mg} / \mathrm{L})\end{array}$ \\
\hline River upstream $^{\mathrm{i}}$ & 21 & 3 & 0.02 & 0.1 & 0.55 \\
WWTP effluent $^{\mathrm{W}}$ & 8 & 9 & 0.90 & 2.4 & 6.40 \\
ATT effluent $^{\mathrm{j}}$ & $<1$ & 2 & 0.10 & 0.9 & 1.90 \\
CTT effluent $^{\mathrm{j}}$ & 2 & 3 & 0.10 & 1.0 & 6.00 \\
\hline
\end{tabular}

a. Wastewater Treatment Plant

b. Advanced Tertiary Treatment

c. Conventional Tertiary Treatment

d. Total Suspended Solids

e. Biochemical Organic Demand

f. Orthophosphate Phosphorus

g. Ammonia Nitrogen

h. Nitrate Nitrogen

i. Daily average values from June to September 2009-2012 (Gobierno de Navarra 2013)

j. Effluent quality based on Asano et al. (2007)

\section{CEA Methodology}

The steps of CEA as a method to obtain an environmental-economic indicator of each alternative in our case study are as follows:

Identifying or defining alternatives to be evaluated

Two CCWT alternatives are compared with a DWWT alternative and two treatment flow rates (option 1 and option 2) are consider for each one, as summarised on Table 2. 
Table 2. Alternatives and options assessed.

\begin{tabular}{|c|c|c|c|c|}
\hline \multirow{2}{*}{ Alternatives } & \multicolumn{2}{|c|}{ Option 1} & \multicolumn{2}{|c|}{ Option 2} \\
\hline & Facilities & $\mathrm{Q}\left(\mathrm{m}^{3} / \mathrm{s}\right)$ & Facilities & $\mathrm{Q}\left(\mathrm{m}^{3} / \mathrm{s}\right)$ \\
\hline $\mathbf{A T T}^{\mathbf{a}}$ & Ultrafiltration & 0.143 & Ultrafiltration & 0.250 \\
\hline $\mathbf{C T T}^{\mathrm{b}}$ & $\begin{array}{l}\text { Coagulation- } \\
\text { flocculation + } \\
\text { settling tank + } \\
\text { sand filter }\end{array}$ & 0.143 & $\begin{array}{l}\text { Coagulation- } \\
\text { flocculation + } \\
\text { settling tank + } \\
\text { sand filter }\end{array}$ & 0.250 \\
\hline \multirow[t]{14}{*}{$\mathbf{S M}^{\mathrm{c}}$} & $H M B R^{d} 1$ & 0.001 & $H M B R^{d} 1$ & 0.001 \\
\hline & $H M B R^{d} 2$ & 0.002 & $H M B R^{d} 2$ & 0.002 \\
\hline & $H M B R^{d} 3$ & 0.003 & $H M B R^{d} 3$ & 0.003 \\
\hline & $H M B R^{d} 4$ & 0.007 & $H M B R^{d} 4$ & 0.007 \\
\hline & $H M B R^{d} 5$ & 0.011 & $H M B R^{d} 5$ & 0.011 \\
\hline & $H M B R^{d} 6$ & 0.012 & $H M B R^{d} 6$ & 0.012 \\
\hline & $H M B R^{d} 7$ & 0.020 & $H M B R^{d} 7$ & 0.020 \\
\hline & $H M B R^{d} 8$ & 0.023 & $H M B R^{d} 8$ & 0.023 \\
\hline & $H M B R^{d} 9$ & 0.028 & $H M B R^{d} 9$ & 0.028 \\
\hline & $H M B R^{d} 10$ & 0.036 & $H_{M B R}^{d} 10$ & 0.036 \\
\hline & & & $H M B R^{d} 11$ & 0.036 \\
\hline & & & $H M B R^{d} 12$ & 0.036 \\
\hline & & & $H_{M B R}^{d} 13$ & 0.036 \\
\hline & Total: & 0.143 & Total: & 0.250 \\
\hline
\end{tabular}

a. Advanced Tertiary Treatment

b. Conventional Tertiary treatment

c. Sewer Mining

d. Hybrid Membrane Bioreactor

The DWWT alternative involves the implementation of HMBR as SM facilities in those parks or green areas of the urban area and surroundings traversed by the sewer system where a reclaimed water demand exists (Figure 2). HMBR has been proposed as a suitable technology for sewer mining purposes (Díez et al. 2010) and its suitability to serve as a decentralized treatment facility was assessed at pilot-scale treating municipal wastewater (Rodríguez-Hernández et al. 2013). HMBR facilities were sized based on the irrigation water demand values calculated by the FAO-Penman Montheit method 
(Allen et al. 1998), identifying the potential irrigation zones on the city and its surroundings.It should be noted that in Spain water reuse projects are regulated by the Royal Decree 1620/2007 which establishes the accepted uses and quality criteria of the reclaimed water.Hence, direct potable reuse is not permitted in Spain. Option 1 and 2 exemplify two SM implementation levels, which would be achieved as the water demand increased.

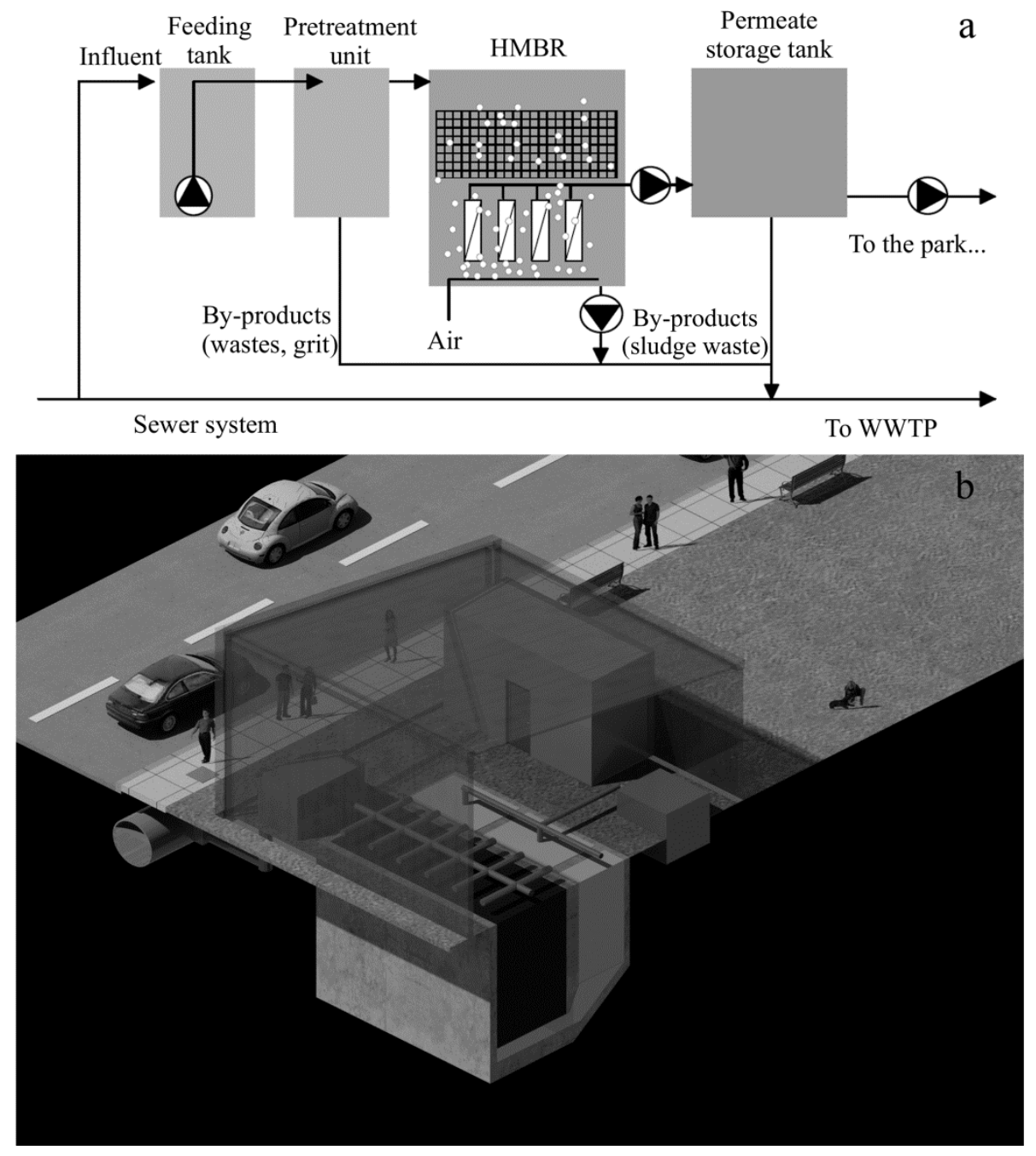

Figure 2. (a) Hybrid Membrane Bioreactor-Sewer Mining (HMBR-SM) facility scheme and components, and (b) a graphic visual representation of a possible HMBR-SM facility implementation. 
The CWWT alternatives are based on the implementation of an advanced (ATT) or a conventional tertiary treatment (CTT) to treat the same fraction of WWTP discharge considered in DWWT alternative. ATT consists of ultrafiltration membrane modules while CTT refers to the well-known tertiary treatment consisting of coagulation-flocculation followed by settling tank and sand filter.

\section{Estimating costs of each alternative}

Following Aulong et al.(2009), Berbel et al. (2011) and Molinos-Senante et al.(2011), costs are the direct financial costs of each alternative while social costs are excluded. Hence, the CEA is a financial analysis instead of an economic analysis.

The costs of each alternative involve investment costs (IC) and operation and maintenance costs (OMC) adjusted for the time period in which they occur. The total annualized equivalent cost (TAEC) is then calculated (Molinos-Senante et al.2012) (Equation (1)):

$$
\mathrm{TAEC}=\frac{\mathrm{r}(1+\mathrm{r})^{\mathrm{t}}}{(1+\mathrm{r})^{\mathrm{t}}-1} \mathrm{IC}+\mathrm{OMC}
$$

where TAECis the total annualized equivalent cost in $€ /$ year; ICis the investment cost in $€$; OMCare the operational and maintenance costs in $€ /$ year; ris the discount rate; and $t$ is the useful life of the project or alternative.

The wastewater extracted in the SM alternative must be deducted from the WWTP influent, and it also replaces an amount of fresh water which therefore is not necessary to be treated in the drinking water treatment plant (DWTP). These costs savings are considered in the economic assessment. Thus, the TAEC is as follows (Equation (2)):

$$
\mathrm{TAEC}=\frac{\mathrm{r}(1+\mathrm{r})^{\mathrm{t}}}{(1+\mathrm{r})^{\mathrm{t}}-1} \mathrm{IC}+\mathrm{OMC}-\mathrm{CS}
$$


where CSare the costs savings in $€ /$ year.

Estimating the effectiveness of each alternative

The effectiveness index (EI) calculation depends on the defined environmental objectives. In this paper, the effectiveness of each alternative is set as the improvement in the river water quality with respect to the current situation, assessed by a water quality index, WQI (Equation (3)):

$$
\mathrm{EI}=\mathrm{WQI}(\text { alternative })-\mathrm{WQI}(\text { current state) }
$$

Water quality is characterized by the following physicochemical parameters: Suspended Solids, Biochemical Oxygen Demand, Ammonium, Nitrate and Total Phosphorous.

The impact of wastewater discharge into the river is estimated by applying the initial mixing model for all the pollutants considered (Patry and Chapman 1989). The obtained concentrations of pollutants in the river are finally normalized in a single WQI, determined by (Equation (4)):

$$
\mathrm{WQI}=\frac{\sum_{\mathrm{i}} \mathrm{C}_{\mathrm{i}} \mathrm{P}_{\mathrm{i}}}{\sum_{\mathrm{i}} \mathrm{P}_{\mathrm{i}}}
$$

where $\mathrm{C}_{\mathrm{i}}$ is the normalized value of the physicochemical parameter $\mathrm{i}$ and $\mathrm{P}_{\mathrm{i}}$ is the relative weight assigned to parameter $i . P_{i}$ and $C_{i}$ with the corresponding range of analytical values, are based on Sanchez et al. (2007). The influence of different variables (WWTP discharge flow, river upstream flow, river upstream and WWTP effluent water quality) on EI and cost effectiveness ratio (CER) has been evaluated. Estimating a cost-effectiveness ratio and ranking alternatives

Once the cost and the effectiveness of each alternative are estimated, a CER is calculated to rank alternatives. The CER represents an environmental-economic 
indicator of each alternative; therefore it provides very useful information to decision makers for environmental planning.

The standard CER (European Commission 2003) is defined as (Equation (5)):

$$
\mathrm{CER}=\frac{\mathrm{TAEC}}{\mathrm{EI}}
$$

where CER is the cost-effectiveness ratio, TAEC is the total annualized equivalent cost and $\mathrm{EI}$ is the effectiveness index.

The best alternative is the one with the lowest CER while the worst alternative is the one with the highest CER. The other alternatives fall in between based on their CER.

\section{Sensitivity analysis to account for uncertainty}

Accounting for uncertainty is important in the development of any CEA since uncertainty, could influence the ranking of management options (Berbelet al. 2011, Woods et al. 2013). Regarding cost estimations, higher discount rates favour solutions that are weighted toward future spending, i.e., those with relatively high OMC and lower IC. Based on this statement, the use of different discount rates was proposed to study the possible uncertainty in the TAEC, estimated for each of the alternatives. In particular and following the work of Woods et al. (2013) the two extreme discount rates of $3 \%$ and $9 \%$ were applied to narrow uncertainty.

With respect to effectiveness estimation, twelve scenarios (A-L in Table 3) were simulated to assess the sensitivity to water flows and qualities of the analysis. Minimum and average river upstream flow during dry season and average and a hypothetically reduced discharge flow were considered, in addition to real and hypothetically improved river and discharge water qualities in both cases. 
Table 3. Scenarios characterization.

\begin{tabular}{lcccccccccccc} 
& \multicolumn{11}{c}{ Scenarios } \\
\hline Variables & $\mathrm{A}$ & $\mathrm{B}$ & $\mathrm{C}$ & $\mathrm{D}$ & $\mathrm{E}$ & $\mathrm{F}$ & $\mathrm{G}$ & $\mathrm{H}$ & $\mathrm{I}$ & $\mathrm{J}$ & $\mathrm{K}$ & $\mathrm{L}$ \\
\hline River flow $\left(\mathrm{m}^{3} / \mathrm{s}\right)$ & 0.5 & 1 & 1 & 0.5 & 1 & 1 & 0.5 & 1 & 1 & 0.5 & 1 & 1 \\
Discharge flow $\left(\mathrm{m}^{3} / \mathrm{s}\right)$ & 1 & 1 & 0.5 & 1 & 1 & 0.5 & 1 & 1 & 0.5 & 1 & 1 & 0.5 \\
River quality & $\mathrm{R}^{\mathrm{a}}$ & $\mathrm{R}^{\mathrm{a}}$ & $\mathrm{R}^{\mathrm{a}}$ & $\mathrm{H}^{\mathrm{b}}$ & $\mathrm{H}^{\mathrm{b}}$ & $\mathrm{H}^{\mathrm{b}}$ & $\mathrm{R}^{\mathrm{a}}$ & $\mathrm{R}^{\mathrm{a}}$ & $\mathrm{R}^{\mathrm{a}}$ & $\mathrm{H}^{\mathrm{b}}$ & $\mathrm{H}^{\mathrm{b}}$ & $\mathrm{H}^{\mathrm{b}}$ \\
Discharge quality & $\mathrm{R}^{\mathrm{a}}$ & $\mathrm{R}^{\mathrm{a}}$ & $\mathrm{R}^{\mathrm{a}}$ & $\mathrm{R}^{\mathrm{a}}$ & $\mathrm{R}^{\mathrm{a}}$ & $\mathrm{R}^{\mathrm{a}}$ & $\mathrm{H}^{\mathrm{b}}$ & $\mathrm{H}^{\mathrm{b}}$ & $\mathrm{H}^{\mathrm{b}}$ & $\mathrm{H}^{\mathrm{b}}$ & $\mathrm{H}^{\mathrm{b}}$ & $\mathrm{H}^{\mathrm{b}}$ \\
\hline
\end{tabular}

a. Daily average quality values during dry season (see Table 1)

b. Hypothetically improved quality values

\section{Results and discussion}

\section{Cost Assessment}

This section summarises the results of the economic assessment of the 6 alternatives evaluated in the CEA.Since CTT and membrane filtration are widely spread technologies (Côté et al. 2004, De Carolis et al. 2007, Gavasci et al. 2010, Verrecht et al. 2010, Hai and Yamamoto 2011), their cost assessment was carried out based on Spanish cost estimations as developed by JM Puigdengoles (personal communication, Ecosessions, Environment Sessions (Ecocity and Industry), 28 May 2009) and Iglesias et al. (2010). Since there is no available data about HMBR costs, a theoretical cost function was developed based on the design and costs estimation of six decentralized HMBR facilities to operate in a range between 0.001-0.046 $\mathrm{m}^{3} / \mathrm{s}$ (Equation (6)).

$$
\mathrm{y}=7477 \mathrm{Q}^{-0.295}
$$

where $\mathrm{Q}$ is daily treated flow expressed in $\mathrm{m}^{3} / \mathrm{d}$ ). The main difference between a conventional MBR and the novel HMBR investment as decentralized technologies is the additional cost of the support for biofilm growing, so HMBR investment cost is considered to be higher than MBR. Then, even though HMBR maintenance is expected to be cheaper due to the reduced fouling rate obtained experimentally (RodríguezHernández et al. 2014), in this study OMC values for MBR are applied for HMBR. 
As reported in the methodology section, to narrow uncertainty two extreme discount rates (3\% and 9\%) were applied to calculate the TAEC. The expected life of the proposed wastewater treatment systems was assumed to be 20 years. A global cost savings value of $0.16 € / \mathrm{m}^{3}$ (Equation (2)) has been considered to take into account the decrease in the volume of water treated by WWTP and DWTP in SM alternatives. It must be pointed out that although sludge is not treated in the SM HMBR, as it is discharged into the sewer system it finally reaches the WWTP where it must be managed. Thus, savings in WWTP are related with the water line, not with the sludge line. Other savings costs, such as the potential reduction in the WWTP effluent taxes, have not been considered.

The results of the cost assessment are summarized in Table 4. Regarding IC, there are remarkable differences between the three technologies considered. As expected, CTT is by far the cheapest option, which is due to the high investment costs of membrane-based technologies. In addition, ATT is four times less expensivethan the decentralized option. This results can be explained, firstly, considering that the unitary cost $\left(€ / \mathrm{m}^{3} / \mathrm{d}\right)$ is smaller for ATT in the range of flow rates studied (up to $0.250 \mathrm{~m}^{3} / \mathrm{s}$ ). The effect of economies of scale also increases the difference, because smaller 10 or 13 facilities must be built in the decentralized option, which all together treat the same flow as the single ATT. Finally, the centralized options do not account for the secondary treatment facilities as decentralized ones. As the WWTP providing secondary treatment already exists, only the costs to tertiary treat this effluent are considered. Economies of scale also slightly improve unitary IC for alternatives $2\left(0.250 \mathrm{~m}^{3} / \mathrm{s}\right)$ with respect to alternatives $1\left(0.143 \mathrm{~m}^{3} / \mathrm{s}\right)$.

Table 4. Costs, effectiveness and cost-effectiveness assessment results for the three alternatives and the two flow rate options evaluated.

\begin{tabular}{ll}
\hline Option 1 & Option 2 \\
\hline
\end{tabular}




\begin{tabular}{|c|c|c|c|c|c|c|}
\hline & $\mathrm{SM}^{\mathrm{a}}$ & $\mathrm{CTT}^{\mathrm{b}}$ & $\mathrm{ATT}^{\mathrm{c}}$ & $\mathrm{SM}^{\mathrm{a}}$ & $\mathrm{CTT}^{\mathrm{b}}$ & $\mathrm{ATT}^{\mathrm{c}}$ \\
\hline $\mathrm{IC}^{\mathrm{d}}\left(10^{6} € / \mathrm{y}\right)$ & 10.42 & 0.42 & 2.66 & 16.91 & 0.71 & 4.43 \\
\hline $\mathrm{OMC}^{\mathrm{e}}\left(10^{6} € / \mathrm{y}\right)$ & 0.92 & 0.31 & 0.40 & 1.60 & 0.53 & 0.69 \\
\hline OMC-CS $^{f}\left(10^{6} € / y\right)$ & 0.20 & 0.31 & 0.40 & 0.34 & 0.53 & 0.69 \\
\hline TAEC 3\% g (106 €/y) & 0.52 & 0.32 & 0.48 & 0.85 & 0.55 & 0.82 \\
\hline TAEC 9\% h $(106 € / y)$ & 1.14 & 0.35 & 0.64 & 1.86 & 0.60 & 1.09 \\
\hline EI i & 1.45 & 1.00 & 1.51 & 5.24 & 1.78 & 2.69 \\
\hline CER j (TAEC 3\%) & 0.36 & 0.32 & 0.32 & 0.16 & 0.31 & 0.31 \\
\hline CER k (TAEC 9\%) & 0.79 & 0.35 & 0.42 & 0.35 & 0.34 & 0.41 \\
\hline
\end{tabular}

a. Sewer Mining

b. Conventional Tertiary Treatment

c. Advanced Tertiary Treatment

d. Investment Costs

e. Operational and Maintenance Costs

f. Operational and Maintenance Costs-Costs Savings

g. Total Annualized Equivalent Cost, applying 3\% discount rate

h. Total Annualized Equivalent Cost, applying 9\% discount rate

i. Effectiveness Index

j. Cost-effectiveness Ratio, for the Total Annualized Equivalent Cost applying 3\% discount rate

k. Cost-effectiveness Ratio, for the Total Annualized Equivalent Cost, applying 9\% discount rate

Considering the same treatment flow, the $\mathrm{OMC}$ of the alternatives based on membrane processes (SM and ATT) are higher than those associated with the conventional filtration processes (CTT). This is especially true in the case of SM, with OMC values more than twice those of the other options.

Interestingly, when the cost savings in water and wastewater treatment arising from the SM alternatives are included in the calculation of total costs, SM options turn out to have a TAEC in the range of that of ATT, as long as the discount rate is around $3 \%$. It has to be noted however that applying the higher discount rate (9\%), SM cost nearly doubles that of ATT, in accordance with the high capital costs involved. Therefore, this case study illustrates the importance of considering, during the decision making process, the TAEC as representative parameter of the total costs. 
The cost assessment of the 6 alternatives evaluated is consistent with previous studies (Gavasciet al. 2010, Molinos-Senante et al. 2013) which conclude that conventional filtration is a technology with low IC and OMC while membrane technologies are the most expensive ones.

\section{Effectiveness Assessment}

The resultant effectiveness indexes (EI) for the six alternatives are also displayed in Table 4 As expected, the Arga water quality improvement by reducing the WWTP discharge impact was limited by the slight reduction of pollutants that can be achievable with respect to the current WWTP effluent.

It resulted that SM option would improve river water quality twice the ATT option when $25 \%$ of the average WWTP discharge flow rate is treated (alternative SM2 versus ATT2). In contrast, SM1 and ATT1 effectiveness resulted fairly similar. This can be explained by considering the assessment method implemented in this work. To obtain the WQI, the parameter $\mathrm{C}_{\mathrm{i}}$ varies from 0 to 100 in relation with specific ranges of concentration values for each physicochemical parameter. If the concentration value is above or below the fixed maximum or minimum limit of the range (boundary concentration values), no effect on the WQI is observed. For some parameters, centralized alternatives stay below that boundary value being $\mathrm{C}_{\mathrm{i}}=0$ in these cases. So, that reduction of pollutants is not quantified. If the minimum boundary value is exceeded, WQI will vary significantly revealing the reduction of the river pollution.

In this case study, SM is accomplished by releasing dammed water. In other words, SM alternative makes possible to return a part of the dammed river water to its course. As mentioned, current WWTP actually reaches high effluent quality including nutrient removal, which explains why SM1 and ATT1 obtain very similar river water quality values. However, in those alternatives where treated or released flow increases 
(SM2 and ATT2), differences between SM and ATT efficiency also increase thus overcoming the WQI range lower thresholds and resulting in a higher efficiency. On the other hand, CTT alternatives resulted in slightly smaller EI than ATT alternatives, as expected considering the slightly worst effluent quality of CTT technologies.

The sensitivity analysis of EI to variations in the main factors (flows and qualities of both the river and the discharge, and the percentage of wastewater tertiary treated), is displayed in Figure 3. SM resulted to be clearly the most effective alternative for all the scenarios analyzed except for alternative 1 in scenario A. On the other hand, CTT was always the less effective alternative.

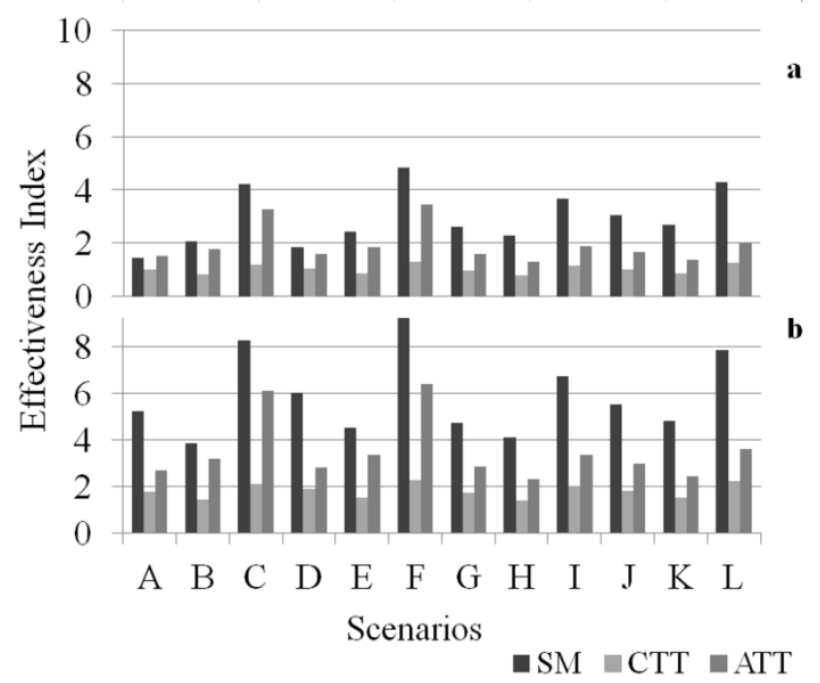

Figure 3. Sensitivity analysis results for Effectiveness Index (a) option 1 and (b) option 2.

Scenario A is defined as the worst situation, with the most adverse values in the dry season. That means that the current discharge flow and river and discharge qualities, with the minimum river flow calculated with $7 \mathrm{Q} 10$ method, are considered. With reference to this scenario, if the river flow is considered greater than WWTP effluent flow (scenarios C, F, I and L) SM effectiveness highly increases, in a higher extent for SM2 than for SM1. ATT effectiveness is also positively affected in these cases, but 
such benefit is slight when higher quality for the river upstream or WWTP effluent (I and L) is considered. These results support that SM effectiveness lies on the dilution effect of released dammed water.

Another important point is the river quality values. EI decreases in scenariosB, E, $\mathrm{H}$ and $\mathrm{K}$ which consider equal flowrate for river upstream and WWTP effluent, revealing how close effluent quality and the river upstream quality are.

\section{Cost-Effectiveness Ratio (CER)}

The CER of each alternative is also shown in Table 5. Results for TAEC 3\% show that SM2 alternative is the most cost-effective solution in this case study while ATT and CTT are almost equivalent. Conventional centralized technologies resulted slightly less effective than ATT, but with a significant lower cost compared to the advanced one. It suggests that, in this case study, membrane technology is not economically suitable when the reclaimed water is finally discharged into the river.

As well as for the EI, the same twelve scenarios were proposed and simulated to check how the CER is influenced on the one hand by the river and WWTP effluent quality and quantity and on the other hand by the discount rate applied, as displayed in Figure 4.

Economic input variables such as the cost of labour, materials, equipment, land and electricity notably affect on MBR costs (Young et al. 2013). Both extreme discount rates express that costs variability, depending on factors beyond.

Considering the lower extreme discount rate (Figures $4 \mathrm{a}$ and $4 \mathrm{~b}$ ), it benefits on TAEC result for those facilities involving high investment cost. Hence, the decentralized alternative treating $25 \%$ of the average WWTP flow rate (SM2) was significantly better than the one treating only $14 \%$ (SM1), especially in scenarios A and D. That means that for SM alternatives, high sensitivity was observed when modifying 
the river and WWTP flow rate, and the quality of the WWTP discharge, while the modification of the river water quality didn't affect significantly the CER related to SM alternatives. Besides, SM2 was the most cost-effective alternative for all cases, while SM1 was the next one for all cases, excluding scenario A. It suggests that sewer mining could be a suitable alternative in this case study.

Regarding the advanced centralized alternatives (ATT1 and ATT2), in general their CER were significantly higher compared to SM1 and SM2. When comparing ATT2 to ATT1, both of them resulted similarly cost-effective for all the scenarios. The sensitivity of the CER was almost the same for both advanced alternatives. However, when the river flow rate was increased, not increasing the WWTP effluent quality (scenarios B, C, E and F), the CER of both advanced alternatives dropped significantly below the CER corresponding to conventional alternatives. For the remaining scenarios, the obtained CER for conventional and advanced alternatives were fairly similar or slightly higher in the case of conventional ones. It suggests that, in this case study, the suitability of membrane technology as a centralized post-treatment could be costeffective compared to conventional alternatives in some specific cases.

When the higher extreme discount rate is considered (Figures $4 \mathrm{c}$ and $4 \mathrm{~d}$ ), CER results drastically change. Sewer mining seems to be the least cost-effective alternative, especially in scenarios A and D treating 14\% (SM1). In contrast, SM2 in these scenarios is slightly more cost-effective than ATT2. As already stated, SM presents high sensitivity when modifying the river and WWTP flow rates, and the quality of the WWTP discharge stream. 


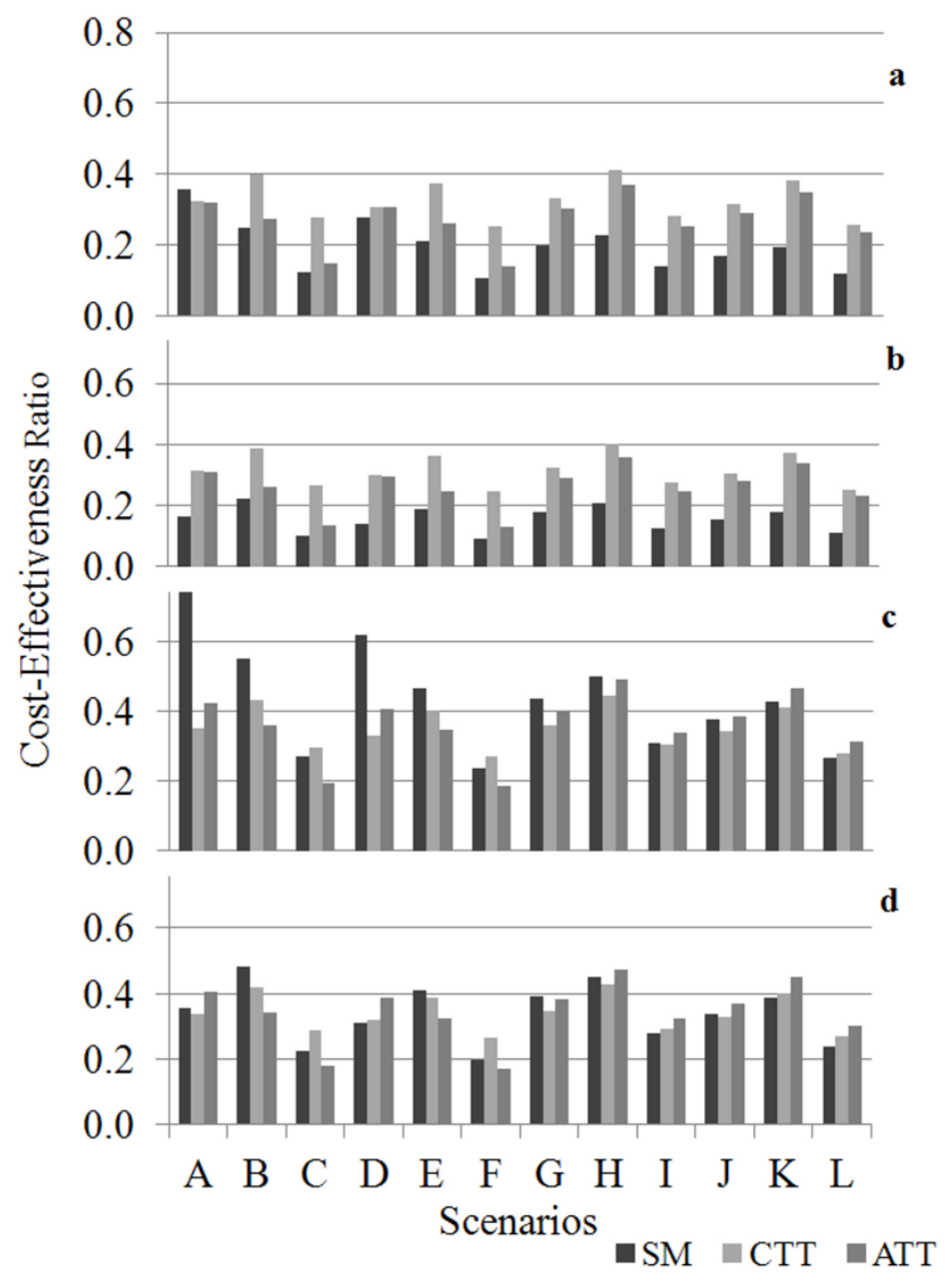

Figure 4. Sensitivity analysis results for Cost-effectiveness Ratio applying (a) Total Annualized Equivalent Cost (TAEC) and 3\% discount rate in option 1, (b) TAEC 9\% in option 1, (c) TAEC $3 \%$ in option 2 and (d) TAEC 9\% in option 2.

\section{Conclusions}

In this paper, cost effectiveness analysis is illustrated as a useful analysis tool to prioritize alternatives. It is applied in a Spanish Mediterranean river basin case study in order to compare wastewater treatment alternatives with the aim of improving river water quality, as WFD requires.

This case study may illustrate a pattern of urban development in cities within a context of water scarcity, where increasing demand and decreasing supply take place. New tools are needed to support the stakeholders in the decision-making process, in 
order to develop integrated water resources management plans in which alternatives of different nature are considered.

Cost Effectiveness Ratio results show that sewer mining is more cost-effective than centralized alternatives (upgrading the WWTP), although based on local construction costs. Nevertheless, the present paper allows for a useful assessment and could also be adapted to better data, if available.

The analysis underlines that those alternatives involving water reclamation technologies give rise to a new water supply, and they therefore lead to cost savings that should be taken into account during CEA implementation. Decentralized management options like sewer mining are often dismissed due to the capital costs involved, but it is suggested that they could be more cost-effective than conventional ones.

\section{ACKNOWLEDGMENTS}

The authors are grateful to Raúl Sáenz de Inestrillas for his help with the preliminary economic assessment and the graphic visual representation.

\section{FUNDING}

This work was supported by the Spanish Ministry of Economics and Competitiveness and the European Regional Development Fund (FEDER) under Grant CTM201236227; Spanish Ministry of Education and Science under Grant CONSOLIDER CSD2007-00055; Navarra de Infraestructuras Locales SA, Namainsa and Mancomunidad de la Comarca de Pamplona, the Navarra Government and the European Union under Grant SOE1/P2/F236; and GeneralitatValenciana government under Grant APOSTD/2013/110.

\section{REFERENCES}

Allen, R. G., et al., 1998. Crop evapotranspiration-Guidelines for computing crop water requirements-FAO Irrigation and drainage paper 56 [online]. FAO, Rome. Available from: http://www.fao.org/docrep/x0490e/x0490e00.htm [Accessed January 2013].

Álvarez-Farizo, B. and Hanley, N., 2006. Improving the process of valuing non-market benefits: Combining citizens' juries with choice modelling. Land Economics, $82(3), 465-478$. 
Arévalo, J., et al., 2013. Removal performance of heavy metals in MBR systems and their influence in water reuse. Water Science and Technology, 67(4), 894-900.

Asano, T., et al.,2007. Water reuse, issues, technologies and applications. McGraw-Hill Professional, New York, NY.

Aulong, S., Bouzit, M. and Dörfliger, N., 2009. Cost-effectiveness analysis of water management measures in two River Basins of Jordan and Lebanon. Water Resources Management, 23(4), 731-753.

Balana, B. B., Vinten, A. and Slee, B., 2011. A review on cost-effectiveness analysis of agri-environmental measures related to the EU WFD: Key issues, methods, and applications. Ecological Economics, 70(6), 1021-1031.

Berbel, J., Martín-Ortega, J. and Mesa, P., 2011. A cost-effectiveness analysis of watersaving measures for the water framework directive: the case of the Guadalquivir River Basin in Southern Spain. Water Resources Management, 25(2), 623-640.

Blanco-Gutiérrez, I., Varela-Ortega, C. and Flichman, G., 2011. Cost-effectiveness of groundwater conservation measures: A multi-level analysis with policy implications. Agricultural Water Management, 98(4), 639-652.

Butler, R. and MacCormick, T., 1996. Opportunities for decentralized treatment, sewer mining and effluent re-use. Desalination, 106(1), 273-283.

Castiella, J., Pérez, C. and Sanz, L., 2007. Documento técnico para la participación pública en la Cuenca del Arga [online]. [Public participation on the Arga River Basin Technical report]. Available from: http://www.crana.org/themed/crana/files/docs/136/232/dossier_cuenca_arga.pdf [Accessed January 2013].

Chanan, A. and Woods, P., 2006. Introducing total water cycle management in Sydney: a Kogarah Council initiative. Desalination, 187(1), 11-16.

Cooper, S. D., et al., 2013. The effects of land use changes on streams and rivers in mediterranean climates. Hydrobiologia, 719(1), 383-425.

Côté, P., Masini, M. and Mourato, D., 2004. Comparison of membrane options for water reuse and reclamation. Desalination, 167, 1-11.

De Carolis, J., et al., 2007. Cost trends of MBR systems for municipal wastewater treatment. Proceedings of the Water Environment Federation, 13-17 October 2007 San Diego: Water Environment Federation, 3407-3418.

Díez, R., et al., 2010. Ecological sanitation based on MBfR (Membrane Biofilm Reactor) for sewage reuse. Design, technology, refurbishment and management 
of buildings 37th World Congress on Housing, 26-29 October 2010 Santander (Spain). [CD-ROM]. Santander: Universidad de Cantabria.

Dobbie, M. F. and Brown, R. R., 2013. Transition to a water-cycle city: sociodemographic influences on Australian urban water practitioners' risk perceptions towards alternative water systems. Urban Water Journal, (ahead-ofprint), 1-17.

González del Tánago, M., et al., 2012. River restoration in Spain: theoretical and practical approach in the context of the European Water Framework Directive. Environmental Management, 50(1), 123-139.

European Commission, 2003. Common Implementation Strategy for the Water Framework Directive (2000/60/EC) Guidance Document No 1 Economics and the Environment - The Implementation Challenge of the Water Framework Directive [online] Available from: http://ec.europa.eu/environment/water/waterframework/objectives/pdf/strategy2.pdf [Accesed April 2013].

European Commission, 2007. Communication from the Commission to the European Parliament and the Council - Towards sustainable water management in the European Union - First stage in the implementation of the Water Framework Directive 2000/60/EC [online] Available from: http://ec.europa.eu/environment/archives/water/implrep2007/pdf/sec_2007_036 2_en.pdf [Accessed April 2013].

Gavasci, R., Chiavola, A. and Spizzirri, M., 2010. Technical-economical analysis of selected decentralized technologies for municipal wastewater treatment in the city of Rome. Water Science and Technology, 62(6), 1371-1378.

Grantham, T. E., Figueroa, R. and Prat, N., 2013. Water management in Mediterranean river basins: a comparison of management frameworks, physical impacts, and ecological responses. Hydrobiologia, 719(1), 451-482.

Gobierno de Navarra, 2013. Red de control de la calidad físico-química de las aguas superficiales [online] [Physicochemicalquality control networkforthewaterbodies] Availablefrom: http://www.navarra.es/home_es/Temas/Medio+Ambiente/Agua/Documentacion/ Memorias/RedFisicoQuimica.htm [Accessed June 2013].

Hai, F. I. and Yamamoto, K., 2011. Membrane Biological Reactors.In: P. Wilderer, ed. Treatise on Water Science. UK: Elsevier, 571-613. 
Iglesias, R., et al., 2010. Water reuse in Spain: data overview and costs estimation of suitable treatment trains. Desalination, 263(1), 1-10.

Jabornig, S., 2014. Overview and feasibility of advanced grey water treatment systems for single households. Urban Water Journal, 11(5), 361-369.

Kamal, A., et al., 2008. Domestic wastewater management in South and Southeast Asia: the potential benefits of a decentralised approach. Urban Water Journal, 5(4), 345-354.

Kraemer, J. T., et al., 2012. A practitioner's perspective on the application and research needs of membrane bioreactors for municipal wastewater treatment. Bioresource Technology, 122, 2-10.

Le-Minh, N., et al., 2010. The application of membrane bioreactors as decentralised systems for removal of endocrine disrupting chemicals and pharmaceuticals. Water Science and Technology, 61 (5), 1081-1088.

Libralato, G., VolpiGhirardini, A. and Avezzù, F., 2012. To centralise or to decentralise: An overview of the most recent trends in wastewater treatment management. Journal of Environmental Management, 94(1), 61-68.

Martín-Ortega, J., 2012. Economic prescriptions and policy applications in the implementation of the European Water Framework Directive. Environmental Science \& Policy, 24, 83-91.

Massoud, M.A., Tarhini, A. and Nasr, J.A., 2009. Decentralized approaches to wastewater treatment and management: applicability in developing countries. Journal of Environmental Management, 90(1), 652-659.

McFallan, S. and Logan, I., 2008. Barriers and drivers of new public-private infrastructure: sewer mining [online]. Brisbane, Queensland University of Technology. Available from: http://eprints.qut.edu.au/26976/1/CIBE_Sewer_Mining_Case_Study_final_July. pdf [Accesed March 2013].

Mewes, M., 2012. Diffuse nutrient reduction in the German Baltic Sea catchment: Costeffectiveness analysis of water protection measures. Ecological Indicators, 22, $16-26$.

Molinos-Senante, M., Hernández-Sancho, F. and Sala-Garrido, R., 2011. Assessing disproportionate costs to achieve good ecological status of water bodies in a 
Mediterranean river basin. Journal of Environmental Monitoring, 13(8), 20912101.

Molinos-Senante, M., et al., 2012. Assessment of wastewater treatment plant design for small communities: Environmental and economic aspects. Science of the Total Environment, 427, 11-18.

Molinos-Senante, M., Hernández-Sancho, F. and Sala-Garrido, R., 2013. Tariffs and cost recovery in water reuse. Water Resources Management, 27(6), 1797-1808.

Norton-Brandão, D., Scherrenberg, S. M. and van Lier, J. B., 2013. Reclamation of used urban waters for irrigation purposes-a review of treatment technologies. Journal of Environmental Management, 122, 85-98.

Orden ARM/2656, 2008, por la que se aprueba la instrucción de planificación hidrológica. BOE 229, 38472-38582. [Ministry of environment, rural and marine affairs order which approves the hydrological planning instruction. State Official Journal 229, 38472-38582].

Panagopoulos, Y., Makropoulos, C. and Mimikou, M., 2013. Multi-objective optimization for diffuse pollution control at zero cost. Soil Use and Management, 29(s1), 83-93.

Patry, G.G. and Chapman, D.T., 1989. Dynamic Modeling and Expert Systems in Wastewater Engineering. Chelsea: Lewis.

Perní, A. and Martínez-Paz, J.M., 2013. A participatory approach for selecting costeffective measures in the WFD context: The Mar Menor (SE Spain). Science of the Total Environment, 458, 303-311.

Poustie, M. S., et al., 2014. Sustainable urban water futures in developing countries: the centralised, decentralised or hybrid dilemma. Urban Water Journal, (ahead-ofprint), 1-16.

Rodríguez-Hernández, L., et al.,2012. Evaluation of a hybrid vertical membrane bioreactor (HVMBR) for wastewater treatment. Water Science and Technology, 65(6), 1109-1115.

Rodríguez-Hernández, L., et al., 2013. Hybrid membrane bioreactor application for decentralized treatment and reuse. Desalination and Water Treatment, 51(1012), 2467-2473.

Rodríguez-Hernández, L., Esteban-García, A.L. and Tejero, I., 2014. Comparison between a fixed hybrid membrane bioreactor and a conventional membrane 
bioreactor for municipal wastewater treatment: A pilot-scale study. Bioresource Technology, 152, 212-219.

Sartor, M., Kaschek, M. and Mavrov, V., 2008. Feasibility study for evaluating the client application of membrane bioreactor (MBR) technology for decentralised municipal wastewater treatment in Vietnam. Desalination, 224(1), 172-177.

Smakhtin, V. U., 2001. Low flow hydrology: a review. Journal of Hydrology, 240(3), 147-186.

Suriyachan, C., Nitivattananon, V. and Amin, A.T.M., 2012. Potential of decentralized wastewater management for urban development: Case of Bangkok. Habitat International, 36(1), 85-92.

Sánchez, E., et al., 2007. Use of the water quality index and dissolved oxygen deficit as simple indicators of watersheds pollution. Ecological Indicators, 7(2), 315-328.

Van Engelen, D., et al., 2008. Cost-effectiveness analysis for the implementation of the EU Water Framework Directive. Water Policy, 10(3), 207-220.

Verrecht, B., et al., 2010. The cost of a large-scale hollow fibre MBR. Water Research, 44(18), 5274-5283.

Vinten, A.J.A., et al., 2012. Application of the WFD cost proportionality principle to diffuse pollution mitigation: a case study for Scottish Lochs. Journal of Environmental Management, 97, 28-37.

Woods, G.J., et al., 2012. Centralized versus decentralized wastewater reclamation in the Houghton area of Tucson, Arizona. Journal of Water Resources Planning and Management, 139(3), 313-324.

Xenarios, S. 2009. Developing an ecological-economic assessment framework for urban wastewater systems: the case of Athens and Vils wastewater systems. Urban Water Journal, 6(2), 147-167.

Young, T.,Smoot, S., Peeters, J. and Côté P., 2013. When does building an MBR make sense? How variations of local construction and operating cost parameters impact overall project economics. $86^{\text {th }}$ Annual Water Environment Federation Conference Proceedings, 5-9 October 2013 Chicago: Water Environment Federation, 6354-6365. 